\title{
Maps, Figures, Table
}

\section{Maps}

I. Area of field research in Nepal (shaded region) $\quad x$

2. Population density of Tamang in Nepal I9

\section{Figures}

I. Mythic models of social differentiation 37

2. Tamdungsa houses and dry fields 39

3. Young Tamang women in festival finery 63

4. Elementary affinal relations among Tamang 66

5. Structure of Tamdungsa divinities 90

6. A lambu sacrificing to Shyihbda I 29

7. A bombo erecting a life-force sapling I 55

8. Tamang raised altar for the festival of Chhechu $\quad$ I77

9. Tormo and paintings on a raised altar $\quad 178$

Io. Lamas chanting at a death feast I86

II. Exchanges and elementary structure of the memorial death $\begin{array}{ll}\text { feast for a dead male } & 197\end{array}$

I2. Principal ashyang and the grasping mha in a matrilateral cross-cousin marriage

I3. Death print

\section{Table}

I. Tamang-speaking population in districts surrounding Kathmandu, I97I census 


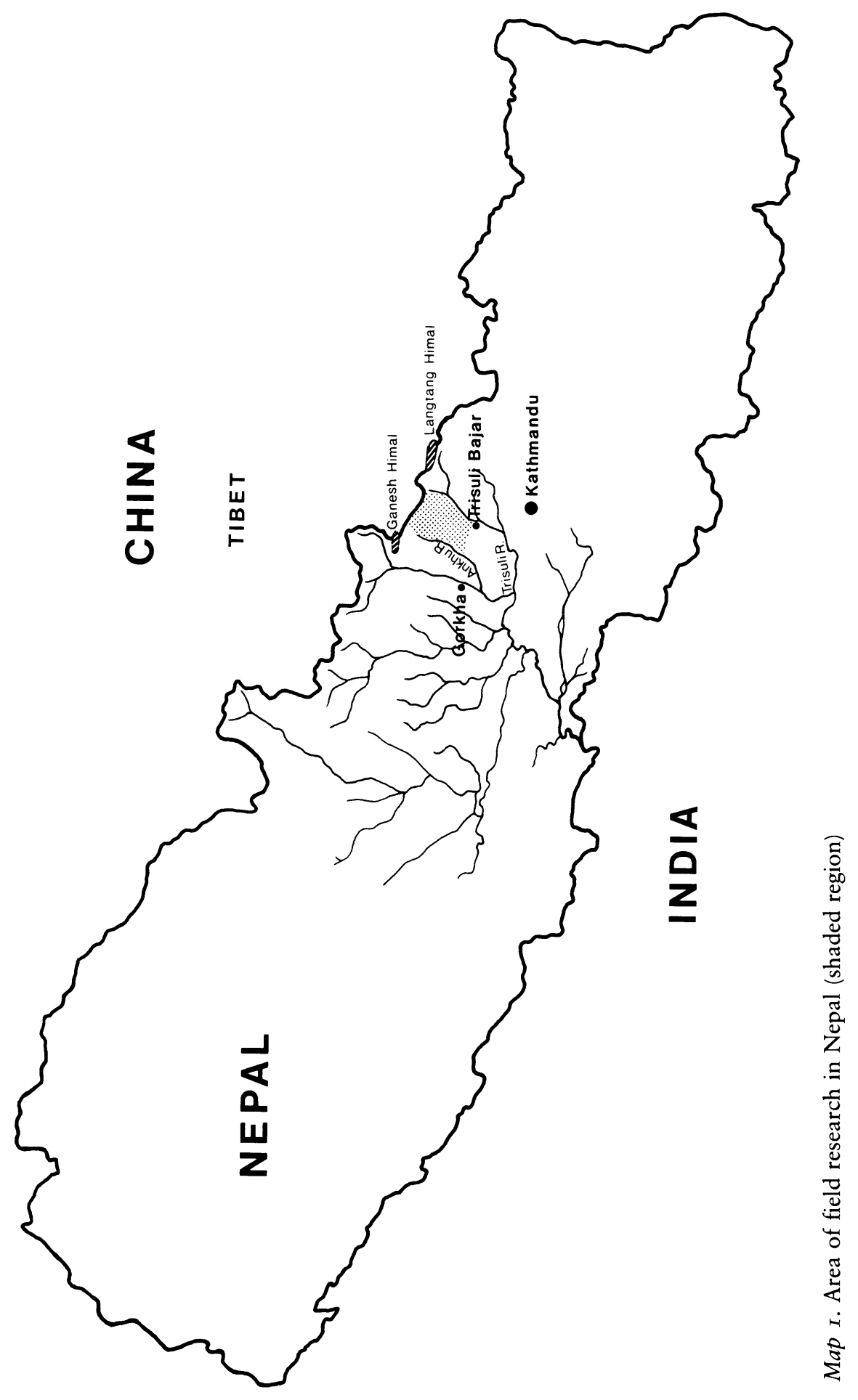

